Kraków

\title{
Obraz zagrożeń w polskiej świadomości społecznej w świetle krytycznej teorii bezpieczeństwa
}

\begin{abstract}
Streszczenie: Jako przedmiot i temat publicznego dyskursu bezpieczeństwo Polaków zwykle jest zredukowane do bezpieczeństwa militarnego państwa. Tymczasem badania pokazują, że większość z nas myśli o bezpieczeństwie inaczej (troszcząc się głównie o swój byt i sprawy socjalne w kontekście bliskiego otoczenia), zgodnie zresztą z podzielanym systemem wartości prywatnych i zbiorowych. Artykuł ilustruje, jak bardzo sposób rozumienia bezpieczeństwa przez zwykłych ludzi odbiega od oficjalnego języka, którym posługują się generałowie, politycy i inni eksperci. Przeprowadzona analiza wybranych przykładów oficjalnego dyskursu o bezpieczeństwie prowadzi do wniosku, że składają się nań trzy składowe odmiany języka, przyczyniające się do zasadniczych problemów komunikacyjnych. Są to: dominujący żargon środowiska zawodowego oficerów-dowódców i oficerów-pedagogów, odmiana języka administracyjno-urzędowego oraz abstrakcyjny język akademickich ekspertów badających stosunki międzynarodowe. Artykuł napisany jest z perspektywy krytycznej teorii bezpieczeństwa i opiera się na danych pochodzących z reprezentatywnych dla ogółu Polaków badań społecznych.
\end{abstract}

Słowa kluczowe: krytyczna teoria bezpieczeństwa, dyskurs bezpieczeństwa, wartości zbiorowe, analiza semantyczna

Aby czuć się bezpiecznie, wszyscy powinniśmy się w tym przede wszystkim dobrze orientować. [...] [B]ezpieczeństwo to nie tylko sprawa państwa, to sprawa każdego z nas, naszych rodzin i spoteczności lokalnych.

gen. Stanisław Koziej ${ }^{1}$

Krytyczna postawa oznacza przyjęcie rygorystycznej zasady sceptycznego dopytywania się, a nie podejrzliwość czy brak zaufania [...]. Ale jest niq również uznanie, że sami jesteśmy ukształtowani poprzez określone reżimy prawdy, idei, teorii i sposobów myślenia, które umożliwily krytykę. Być krytycznym [badaczem] to także myśleć refleksyjnie, rozwijają zdolności ujmowania samego siebie, abstrakcyjnie i rozumowo, w obrębie szerszego, heterogenicznego kontekstu.

C.A.S.E. Collective, 2006, s. 476

\section{Krytyczne podejście do badań bezpieczeństwa}

B ezpieczeństwo ma dla nas wysoką wartość, podobnie jak inne abstrakcyjne i jednoznacznie pozytywne stany rzeczy. Jego istotą jest odczucie przebywania w niezmiennym, trwałym porządku, który nam odpowiada, i którego utrzymanie nie wymaga od nas żadnej specjalnej troski. Etymologicznie, przymiotnik „bezpieczny” pochodzi

${ }^{1}$ Fragment wypowiedzi generała S. Kozieja, szefa Biura Bezpieczeństwa Narodowego w latach 2010-2015, promującej Biała księgę bezpieczeństwa narodowego na witrynie tzw. Strategicznego Przeglądu Bezpieczeństwa Narodowego, http://www.spbn.gov.pl/, 7.02.2015. 
od wyrażenia „bez pieczy” (opieki, ochrony) - jesteśmy subiektywnie bezpieczni, gdy odczuwamy relaksującą pewność, że nic nam nie zagraża; dobrze, gdy towarzyszy temu obiektywny $\mathrm{b}$ rak takowych zagrożeń (co nie zawsze musi być prawda). Specyficzne właściwości semantyczne pojęcia bezpieczeństwa są wyznaczane przez ramy czasu i przestrzeni: poczucie bezpieczeństwa nie powinno być doraźne (cóż to znaczy pomyśleć ,jestem w tej chwili bezpieczny" - a co będzie za chwilę?) i powinno rozciagać się jak najszerzej, poza obszar naszych osobistych doświadczeń. W pojęciu bezpieczeństwa mieści się gwarancja, że ów niewymagający od nas troski pozytywny stan będzie zarówno trwały, jak i obejmujący wszelkie możliwe aspekty i zakresy potencjalnych zagrożeń.

Ustalenie, że istnieje obiektywne bezpieczeństwo danego podmiotu w danej sytuacji zwykle jest niezmiernie trudne i złożone. Najprostszym, elementarnym sposobem jest odwołanie się do logiki negacji zagrożeń - przyczyn strachu - będącej podstawą tzw. negatywnej definicji bezpieczeństwa. Podobnie jak o zdrowiu, wolności, pokoju etc. najczęściej mówimy skupiając się na chorobach, zniewoleniu czy wojnach - również powszechny dyskurs bezpieczeństwa opiera się na badaniu wieloaspektowych $\mathrm{z}$ a g r o ż e ń. Jest to naturalne ze względu na charakter samego pojęcia. Co może zastanawiać, to zasadnicza nieprzystawalność nazw i znaczeń stosowanych w mowie potocznej do języka charakterystycznego dla publicznych dyskursów bezpieczeństwa. W takich przypadkach, niejako automatycznie, pojęcie bezpieczeństwa jest zawężane do bezpieczeństwa o s o b i s t e g o w kontekście zagrożeń m i 1 i t a r n y c h. Nie dziwi dominujący kontekst bezpieczeństwa militarnego - dziwi natomiast całkowity brak szerszego, pogłębionego spojrzenia na powiązane z nim rozliczne aspekty naszego poczucia bezpieczeństwa.

Taki redukcjonizm zamyka dostęp do wiedzy na temat całego kompleksu czynników natury subiektywnej, odczuciowej i oddolnej (odspołecznej), jak np. fundamentalnej kwestii wyrażającej się w pytaniu: jak zwykli ludzie (w opozycji do reprezentujących państwo polityków i strategów) rozumieją i odczuwają wszystko to, co składa się na ich bezpieczeństwo? Czym w swojej istocie jest bezpieczeństwo? Z czyim bezpieczeństwem się utożsamiamy? Jakie strategie jego zapewnienia podzielamy? Kto jest „zabezpieczany" przez dany porządek, przeciw komu, przeciw jakiemu zagrożeniu jest „zabezpieczany"? (Sheehan, 1999, s. 4). Wymienione pytania prowadzą do kolejnych, formułowanych przez zwolenników odmiennych sposobów naukowego myślenia o bezpieczeństwie. Przykładowo, szkoła kopenhaska, wprowadzając koncept sekurytyzacji (Buzan, Wæver, Wilde, 1998, s. 23-26), na pierwszym planie stawia problem instrumentalizowania bezpieczeństwa przez polityków: Kto definiuje i gwarantuje bezpieczeństwo? Które zagadnienia określa on jako kluczowe? Dlaczego, z jakimi skutkami, w jakich okolicznościach to czyni?

Tradycyjne, rutynowe „badania bezpieczeństwa”, rozwijane w cieniu zimnej wojny, oferują obecnie dość ograniczony zasób możliwości poznawczych. Zakładają prosty model, którego centrum pojęciowe stanowi zagregowane, bliżej niesprecyzowane „bezpieczeństwo”, dopełnione jakimś przedmiotowym określeniem - na zasadzie „bezpieczeństwo n”, gdzie w miejsce n podstawia się instytucję lub organizację (najczęściej „państwo”), czasem grupę społeczną (jak np. ,naród”, „Polacy”) lub geopolityczne konstrukty przestrzenne („Europa”, „Południowy Kaukaz”). Podstawę teoretyczną stanowią założenia realistycznego podejścia do stosunków międzynarodowych, zgodnie z którymi państwa są głównym podmiotem działań, ale i podstawową jednostką analizy. Jest to perspektywa 
kratocentryczna i geopolityczna - preferuje odgórny, ,generalski” punkt widzenia dużych instytucjonalnych podmiotów ,grających w szachy”, których plansza obejmuje świat w wymiarze globalnym, plan gry zakłada wyłaniające się z nieładu kolejne konflikty i wojny, a możliwe ruchy - strategiczne użycie sił zbrojnych. Zawsze jest to gra o sumie zerowej.

W teorii stosunków międzynarodowych ów prosty model przestał dominować po końcu zimnej wojny. Nadal oczywiście spory toczą i toczyć będą tradycjonaliści, radykałowie i innowatorzy, zwolennicy wąskiego i szerokiego podejścia do studiów nad bezpieczeństwem, koncentracji na badaniach skupiających się na [osiaganiu] pokoju (peace research) lub nieuchronności wojen (Waever, 2004a), kontynuatorzy szkoły frankfurckiej i jej oponenci, czy w końcu zwolennicy realizmu i neorealizmu, liberalizmu i neoliberalizmu oraz konstruktywizmu w teorii stosunków międzynarodowych. Jak już wspomniałem, w samych studiach nad bezpieczeństwem wyróżniają się w Europie co najmniej trzy krytyczne szkoły myśli teoretycznej (Booth, 1991, s. 319; Jones, 1999; Buzan, 1984, Buzan, Waever, de Wilde, 1998). Spójność ich poglądów pozostawia wiele do życzenia, co jest raczej zaletą w procesie pogłębiania i poszerzania wiedzy o naszym bezpieczeństwie. W 2005 roku badacze skupieni w grupie o nazwie C.A.S.E. Collective podjęli próbę teoretycznego skonceptualizowania krytycznych badań nad bezpieczeństwem. Ich manifest (C.A.S.E. Collective, 2006) jest interesującym podsumowaniem „krytycznych zakrętów” i wyzwań współczesnej teorii bezpieczeństwa, jak również ważną próbą wyznaczenia problematyki badań w przyszłości²

Autorzy manifestu słusznie podkreślają że nie powinno być ostrej granicy między działalnością naukową i teoretyczną a praktykami zapewniania bezpieczeństwa przez polityków. Każda analiza obejmująca tak istotne dla wspólnoty zagadnienia jak ludzkie bezpieczeństwo może mieć skutek polityczny - może wpływać na polityczne decyzje. Badania naukowe staj ą s i ę ważne dopiero wtedy, gdy stają się ważne d la k o g o ś w procesie osiagania celu z ty m ki m ś. Dlatego konieczne jest nadrzędne, krytyczne podejście badawcze, oparte na idei dialogu między orientacjami teoretycznymi. Jeśli nie da się na razie zaproponować spójnej krytycznej teorii bezpieczeństwa, która wyjaśniałaby zjawiska na podstawie praw wykraczających ponad konteksty sytuacyjne, trzeba przynajmniej poddać krytycznej analizie i zweryfikować przydatność istniejących obecnie, zarówno tradycyjnych i dominujących, jak i alternatywnych poglądów na temat bezpieczeństwa (C.A.S.E. Collective, 2006, s. 473 i nast.). W tym kontekście wymowny jest teoretyczny wkład wymienionych szkół ${ }^{3}$. Wspólne dla wszystkich tych

${ }^{2}$ W Paryżu spotkali się m.in. Didier Bigo, Jef Huysmans, Michael Williams i Ole Wæver, którego tekst na temat europejskich nowych szkół w studiach nad bezpieczeństwem stał się zaczynem całego przedsięwzięcia (Weaver, 2004b). C.A.S.E. to akronim od 'Critical Approaches to Security in Europe'. Instytucjonalizacja C.A.S.E. stała się możliwa dzięki zaangażowaniu trzech sieci badań bezpieczeństwa w Europe, finansowanych przez Komisję Europejską: ELISE (European Liberty and Security), która w latach 2002-2005 powiązała siedem instytucji reprezentujących krytyczne podejście do bezpieczeństwa, CHALLENGE (The Changing Landscape of European Liberty and Security) - projekt łączący 23 partnerów w latach 2004-2009, oraz działającą w latach 2004-2008 COST Action 24 (The Evolving Social Construction of Threats). Ze strony francuskiej włączyły się również Centre d'Etudes Européennes oraz Institut d'Etudes Politiques de Paris.

${ }^{3}$ Wszystkie te szkoły, a zwłaszcza kopenhaska, w dużym stopniu ograniczają się do Europy - co zresztą jest przyczyną licznych krytycznych opinii formułowanych przez globalistów i np. zwolenników „teorii bezpieczeństwa w III Świecie”. 
tradycji badań bezpieczeństwa w Europie jest wyjściowe założenie, zgodnie z którym dominujące, redukcjonistyczne podejście do militarnego bezpieczeństwa, analizowanego przez pryzmat polityki zagranicznej państwa, powinno być zastąpione szerszym i pogłębionym, krytycznym namysłem nad różnymi punktami widzenia na społeczną naturę współczesnych zagrożeń (McDonald, Browning, 2013). Manifest C.A.S.A. Collective (2006) zwraca uwagę na newralgiczne punkty obecnych kierunków badań. Wyliczane są zagrożenia, wynikające z dość chaotycznego rozwoju współczesnych studiów nad bezpieczeństwem. Można metaforycznie powiedzieć, że jest to rozwój tyle dynamiczny, co przypadkowy, przypominający proces ,,pączkowania”. Podejście krytyczne i idea dialogu nie mogą zakłócać spójności poznawczej.

\section{Polskie imaginaria zagrożeń u progu $2016 \mathrm{r}$.}

Przełom 2015 i 2016 roku obfituje w nowe czynniki wywierające wpływ na poczucie bezpieczeństwa Europejczyków. Są to przede wszystkim: niepewność w związku z konsekwencjami masowego napływu imigrantów z Południa ${ }^{4}$; strach i niepewność w związku z możliwymi atakami terrorystycznymi fundamentalistów islamskich z różnych organizacji ${ }^{5}$, pogarszająca się sytuacja gospodarcza i kryzys finansowy w Unii Europejskiej ${ }^{6}$ (EB 84; EB/EP 84.1) i niepewna przyszłość polityczna Unii w związku kryzysem demokracji i referendum w Wielkiej Brytanii w 2016 roku.

Czynniki te stanowią ważne odniesienie dla poczucia bezpieczeństwa Polaków, na które dodatkowo wpływa niepewność wynikająca z agresywnej, mocarstwowej polityki Rosji Władimira Putina oraz zasadnicze przetasowania polityczne na krajowej scenie politycznej. Jednak jako Polacy przede wszystkim kierujemy się czynnikami lokalnymi. Do takiego wniosku prowadzi analiza porównawcza odpowiedzi na pytania Eurobarometru o zagrożenia dla Europy, Europejczyków, Unii Europejskiej i o zagrożenia dla nas - Polaków.

Obywatele 28 państw Unii, pytani o dwa największe wyzwania/zagrożenia d 1 a Un i i pod koniec 2015 roku, wskazują: napływ imigrantów (54 proc.), terroryzm (28 proc.) oraz stan finansów publicznych krajów UE (15 proc.) (EB 84, s. 15). Pytani o największe wyzwania $\mathrm{dla}$ s w o j e g o $\mathrm{kraj}$ u, odpowiadają: napływ imigrantów (36 proc., +13 ), bezrobocie (36 proc., -6 ), sytuacja gospodarcza (19 proc., -2$)$, koszty życia (14 proc.), opieka społeczna i zdrowotna (14 proc., -4$)$, terroryzm $(11$ proc. +4$)$ (EB 84, s. 16). Odpowiedzi Polaków pytanych o Polskę są jeszcze inne: bezrobocie (37 proc.), rosnące koszty życia (21 proc.), emerytury (20 proc.), opieka zdrowotna i społeczna (20 proc.), sytuacja gospodarcza (17 proc.), imigracja (17 proc.) (EB 84, s. 17).

Znamienne są różnice w postrzeganiu zagrożeń. Wspólne dla Europejczyków (z kilkoma wyjątkami, w tym Polski) są silne obawy przed niekontrolowaną imigracją. Z kolei na terroryzm jako problem „własnego podwórka” wskazuje tylko co dziesiąty Euro-

${ }^{4}$ W samym 2015 roku drogą morską przybyło do Unii Europejskiej ok. 900 tys. osób, przy czym od końca tego roku miesięcznie przybywa ponad 100 tys.

${ }^{5}$ Listopadowe ataki w Paryżu, do których przyznało się tzw. państwo islamskie, przyniosły nie tylko śmiertelne żniwo 130 ofiar, ale i stan wyjątkowy ze wszelkimi tego konsekwencjami.

${ }^{6}$ Kryzys strefy euro, ogromne zadłużenie Grecji, słabnące banki (Deutsche Bank). 
pejczyk (i zaledwie co dwudziesty Polak!). Świadczy to o tym, że nowa fala imigracji oraz terroryzm, jeśli w ogóle są postrzegane w kategorii istotnych zagrożeń, to zagrożeń transnarodowych, może globalnych, które odsuwamy od siebie, „delegując” je na wyższy poziom rozwiązywania problemów (Unii Europejskiej, NATO, oraz bezpośrednio dotkniętych nimi krajów). Badani w 28 krajach Unii zgadzają się obecnie co do tego, że największą zasługą Unii jest właśnie „pokój między państwami członkowskimi” (56 proc.) - a nie „swoboda przepływu ludzi, dóbr i usług w Europie”, która przez długi czas była priorytetem Europejczyków (EB 84, s. 33).

Polscy respondenci w ogóle wyróżniają się specyficznym nastawieniem do zagrożeń. Boimy się utraty pracy i pogarszania się warunków życia (najbardziej ze wszystkich badanych krajów UE boimy się o przyszłe emerytury). Patrzymy na przyszłość pragmatycznie i materialistycznie, troszcząc się przede wszystkim o sprawy indywidualne. W porównaniu z innymi krajami Unii, bez wątpienia, wymiar bezpieczeństwa socjalnego jest dla nas ważniejszy niż bezpieczeństwo militarne. Wyniki Diagnozy społecznej (2015) od pewnego czasu potwierdzają prawidłowość, że „żyjemy w kraju coraz bardziej efektywnych jednostek i niezmiennie nieefektywnej wspólnoty" (Diagnoza, 2015, s. 344). Nie myślimy wspólnotowo, nie potrafimy rozwijać kompetencji w praktycznym stosowaniu wiedzy obywatelskiej, nie ufamy ludziom i instytucjom, pozostajemy mało wrażliwi na publiczne dobro (315-316). Niedawno wykonany przez Instytut Badań Rynkowych i Społecznych sondaż pokazał, że gdyby Polska została zaatakowana przez obce państwo, tylko niecałe 30 proc. z nas stanęłoby w obronie ojczyzny - zdecydowana większość (ponad 66 proc.) przede wszystkim zatroszczyłaby się o siebie i swoich bliskich w miejscu zamieszkania, blisko 17 proc. uciekłoby za granicę. Na powołanie do wojska czekałoby tylko... 12 proc. $^{7}$

Brak kapitału społecznego, nieufność wobec państwa i innych instytucji oraz nastawienie na indywidualny rozwój są dla większości Polaków odniesieniem dla indywidualnej oceny jakości życia. $Z$ badań wynika, że najwyższą wartość mają dla nas: zdrowie (67 proc.), udane małżeństwo (50,3 proc.), dzieci ( 48,7 proc.), praca (30 proc.) i pieniądze (28,3 proc.) (255). Idei „bezpieczeństwa” co prawda nie ma na głównej liście badanych wartości ${ }^{8}$, ale można je odnaleźć w innej części badań poświęconych analizie tzw. indywidualnej jakości życia. Jest to konstrukt złożony, wielowymiarowy ${ }^{9} \mathrm{i}$ wielopiętrowy. Autorzy wykazują, że jednym z dwu czynników łącznie ujmujących wszystkie wymiary badań jest „styl życia”, określany przez stres życiowy, dobrostan społeczny i patologie; z drugim czynnikiem - ,warunkami życia” łączą go dwa wymiary: dobro-

${ }^{7}$ Sondaż IBRIS przeprowadzono w marcu 2015 r. na ogólnopolskiej, reprezentatywnej próbie 1115 osób, metodą wywiadów bezpośrednich z wykorzystaniem urządzeń mobilnych (CAPI). Zob. http:// www.polskatimes.pl/artykul/3790649, sondaz-polacy-nie-chca-walczyc-w-obronie-kraju,id,t.html.

${ }^{8} \mathrm{Na}$ wyniki Diagnozy należy oczywiście patrzeć krytycznie, biorąc pod uwagę jej charakter. Jest projektem naukowym odwołującym się głównie do demograficznych, psychologicznych i statystycznych metod rekonstrukcji tego, jak polskie rodziny określają warunki i jakość życia. Na podstawie bardzo dużej próby (obecnie niemal 12 tys. gospodarstw badanych panelowo) autorom udało się nakreślić zaawansowaną panoramę polskiej świadomości społecznej w okresie ostatnich 15 lat, skupiając się głównie na subiektywnie postrzeganych warunkach życia przez jednostki.

9 Uwzględniane w analizach są wymiary: kapitału społecznego, dobrostanu psychicznego, fizycznego i społecznego, poziomu cywilizacyjnego, dobrobytu materialnego, stresu życiowego i patologii (Diagnoza społeczna, 2015, s. 418-437 oraz 183-198). 
stan psychiczny i dobrostan fizyczny (418-419). Z kolei w wymiarze „stres życiowy” odnajdujemy jako zmienna , zadowolenie ze stanu bezpieczeństwa w miejscu zamieszkania”. Dane pokazują że „bardzo zadowolonych” lub „zadowolonych” Polaków ze stanu bezpieczeństwa w miejscu zamieszkania jest obecnie (koniec 2015 r.) niespełna 56 proc., przy czym wskaźnik ów ponaddwukrotnie wzrósł od 2000 roku (Diagnoza społeczna, s 189). Dane te należy odczytywać w kontekście kompleksowej oceny tego, jak się zmienia jakość naszego życia, przy czym nie bez znaczenia jest systematycznie rosnący poziom ogólnego zadowolenia z życia (w 2015 roku ponad 80 proc. Polaków określała siebie jako „bardzo” i „dosyć szczęśliwi”).

Wymiar wskaźników psychologicznych i społecznych, których przykładem zastosowania jest Diagnoza społeczna, jest odrębny i komplementarny wobec założeń w tradycyjnych, wąskich, „geopolitycznych” studiach nad bezpieczeństwem, przyjmowanych przez polityków i generałów jako kanon wystarczającej wiedzy. Geopolityczny realizm nie traktuje czynników kulturowych, społecznych i „oddolnych” jako istotnych, ponieważ operuje na poziomie regionalnych i globalnych konfliktów militarnych między głównymi podmiotami polityki. Tymczasem subiektywne poczucie bezpieczeństwa wiąże się z ogólnym „dobrostanem społecznym”, patologiami oraz „,dobrostanem psychicznym i fizycznym". Związane jest z poziomem zadowolenia z sytuacji w kraju, zadowolenia z miejsca zamieszkania i przekonania co do stanu bezpieczeństwa (w miejscu zamieszkania). Analizowanie bezpieczeństwa ludzi powinno uwzględniać takie czynniki jak np. poziom stresu życiowego (Diagnoza społeczna, 2015, s. 246-250), związanego nie tylko z warunkami mieszkaniowymi, sąsiadami, ale również jakością społeczeństwa obywatelskiego, systemem indywidualnych wartości i celów oraz poziomem optymizmu co do przyszłości naszego otoczenia międzynarodowego - Unii Europejskiej i NATO. Podsumowując: nie chodzi o to, żeby studia nad bezpieczeństwem Polaków każdorazowo prowadzone były szeroko, kompleksowo i wielowymiarowo - uznajmy to za nieosiągalny w praktyce ideał. Możliwe jest natomiast to, by na etapie definiowania terminów i wskaźników, jak również podczas określania celu i problematyki badań oraz w czasie interpretacji główne wnioski były ujmowane krytycznie, również w szerokim kontekście systemu (układów i hierarchii) wartości, postaw i dynamicznie zmieniających się preferencji polskiego społeczeństwa.

\section{Semantyka bezpieczeństwa w polskiej świadomości}

Z punktu widzenia semantyki wartości „bezpieczeństwo” jest jedną z podstawowych kategorii, stosowanych w badaniach socjolingwistycznych w ostatnich dwudziestu pięciu latach ${ }^{10}$. Celem tych badań jest m.in. rekonstrukcja hierarchii odczuwanych wartości (politycznych, europejskich, indywidualnych i wspólnotowych) oraz rozpoznanie ich podstawowych aspektów semantycznych (zmieniających się znaczeń). Mówiąc prościej, w badaniach takich chodzi o zrekonstruowanie dynamiki tego, jak rozumieja, kategoryzują i wartościują swój świat i swoje życie Polacy. Nawiązując do metodologii badania słów i wyrażeń sztandarowych Walerego Pisarka (2002) oraz dorobku polskiej szkoły

${ }^{10}$ Szeroki opis tej tradycji badań znajduje się w: J. Kołodziej (2011, s. 245-273); patrz również: Pisarek 2002; Bartmiński 2006. 
badania ,języka wartości”, od 2009 roku prowadzone są w Instytucie Europeistyki na Uniwersytecie Jagiellońskim porównawcze analizy wartości europejskich (Kołodziej, 2011). Na ich podstawie można zrekonstruować miejsce „bezpieczeństwa” (bez względu na sposób rozumienia) w systemie wartości podzielanych przez Polaków.

Jednym z wymiarów badań jest porównywalna analiza zmieniających się, dominujących aspektów semantycznych pojęcia bezpieczeństwa (po upływie pięciu lat między 2009, a 2014 rokiem). Podstawą tej części analizy było w sumie 4457 tekstowych otwartych rekordów (Kołodziej, 2011) ${ }^{\mathrm{\Gamma 1}}$. Respondenci, którzy wymienili „bezpieczeństwo” w pierwszej z pięciu preferencji, najczęściej stosowali nazwę podstawową bez dodatkowych, zawężających określeń. W kolejnych preferencjach częściej precyzowano, o jakie „bezpieczeństwo” chodzi. Kategorie te łącznie tworzą roboczą mapę mentalną tego, jak Polacy kojarzą i rozumieją bezpieczeństwo. W odpowiedziach respondentów wyraźnie zarysowało się 6 aspektów semantycznych pojęcia:

(1) Bezpieczny w sensie ogólnym - wolny; niegraniczony pod względem ekspresji przekonań (wolność słowa), wyznania, możliwości swobodnego przemieszczania się w Europie, możliwości podejmowania zatrudnienia i decydowania o samym sobie.

(2) Bezpieczny w sensie gospodarczym - przekonany bądź pewny, że można nieskrępowanie podejmować działalność gospodarcza, przemieszczać się, pracować i zarabiać, realizując swoją przedsiębiorczość w wymiarze międzynarodowym.

(3) Bezpieczny w sensie bytowym, socjalnym, „opiekuńczym” - przekonany bądź pewny, że państwo zadba o wysokie zarobki, zagwarantuje opiekę socjalna, wypłaci emeryturę na godnym poziomie (odniesieniem są płace i zarobki europejskie).

(4) Bezpieczny w wojskowym, tradycyjnym, międzynarodowym sensie - przekonany bądź pewny, że w razie czego granice Polski zostaną obronione (dzięki wspólnotowej polityce europejskiej i NATO, zaufaniu, przyjaźni i wzajemności).

(5) Bezpieczny w sensie przynależności do europejskiej/zachodniej wspólnoty - przekonany bądź pewny, że realną gwarancję stabilnej i dobrej przyszłości stanowią wypracowane w Europie wartości wspólnotowe i ich instrumenty (wspólne korzenie i rozwinięta cywilizacja, wspólny rynek, wspólna waluta, otwarte granice, prawa człowieka, tolerancja, otwartość i solidarność).

(6) Bezpieczny w sensie ,zamknięty w nienaruszalnej kapsule narodu i tradycji” - przekonany bądź pewny, że realną gwarancję stabilnej i dobrej przyszłości stanowi zatrzymanie politycznej integracji Europy, wzmacnianie tożsamości i wartości narodowych, korzeni chrześcijańskich i podkreślanie suwerenności.

Polską specyfiką jest wszechobecne lączenie pojęcia bezpieczeństwa z pojęciem wolności. Najpierw chcemy być wolni, nieskrępowani, by później móc czuć się bezpiecznie. Taką samą sekwencję argumentów odnajdujemy u Karla Poppera w Społeczeństwie otwartym i jego wrogach - słynnym traktacie opisującym dwa typy społeczeństw: otwarte oraz podlegające różnym wersjom historycyzmu. Przestrzegając przed nadmierną aktywnością i zaborczością państwa, mogącą zagrozić demokracji, Popper pisał w rozdziale krytycznie odnoszącym się do spuścizny Marksa: „Musimy planować wolność, a nie tylko

${ }^{11}$ Reprezentatywna grupa dorosłych Polaków udziela do pięciu odpowiedzi na otwarte pytanie (zadane przez ankieterów CBOS) o najważniejsze wartości europejskie. Wyniki są opracowywane na podstawie listy 146 kategorii - językowych reprezentacji pól aksjologicznych. W 2009 roku 1038 respondentów udzieliło 2318 odpowiedzi, a w 2014 roku 1044 respondentów - 2139 odpowiedzi. 
troszczyć się o bezpieczeństwo - przynamniej z tego powodu, że wyłącznie wolność może uczynić bezpieczeństwo bardziej bezpieczne" (Popper, 1947, s. 182).

Bezpieczeństwo rozumiemy zatem w związku z wolnością, konstruujemy je przestrzennie, lokalnie, głównym punktem odniesienia jest nasza rodzina, nasze zdrowie i nasza przyszła, stabilna egzystencja. W tym sensie be zp i e c zeń s tw o bytowe i socjalne jest dla nas ważniejsze od bezpieczeństwa mil it a rn e g o pań stwa. Wypracowaliśmy za to dwie, wzajemnie wykluczające się, mentalne enklawy bezpieczeństwa. Pierwszą jest Europa i Unia Europejska. Europa dostarcza nam wysokich wzorów zachodniej cywilizacji. Tę drugą traktujemy dość instrumentalnie - jako przestrzeń „cywilizacji bezpieczeństwa”, ale również naszych sąsiadów, którym lepiej się powiodło, więc mają wobec nas zobowiązania. Drugą mentalną enklawą bezpieczeństwa jest „,kapsuła narodu i tradycji”, odwołująca się do ahistorycznej idei autarkicznego odbudowywania mocarstwowej i bezpiecznej pozycji Polski własnymi siłami.

\section{Oficjalny dyskurs bezpieczeństwa i sekurytyzacji w Polsce}

Jest w pełni uzasadnione, że o bezpieczeństwie musimy myśleć, często rozmawiać, a politycy, eksperci i generałowie powinni naszego bezpieczeństwa strzec najlepiej, jak tylko się da. To truizm: bezpieczeństwo - w różnych znaczeniach - ma dla nas ogromną wartość. Badania świadomości społecznej przekonują że bezpieczeństwo jest na tyle złożonym fenomenem (wieloznacznym pojęciem, konstruktem społecznym i politycznym), że powinno się doń podchodzić z maksymalną ostrożnością - krytycznie i całościowo, wykorzystując istniejącą wiedzę społeczna. $Z$ tych powodów jest bardzo ważne, w jaki sposób o bezpieczeństwie rozmawiamy p u b l i c z n i e. Niestety, polski dyskurs bezpieczeństwa pozostawia wiele do życzenia, zarówno pod względem formy, jak i spójności.

$\mathrm{Z}$ pewnością jest wiele przyczyn tego stanu rzeczy. Jedną z nich $\mathrm{z}$ pewnością jest to, że stanowi wypadkową kilku odmian języka, spośród których dominuje żargon środowiska zawodowego oficerów-dowódców i oficerów-pedagogów, który rozwijał się, mówiąc w skrócie, z dala od językoznawców i specjalistów od kultury komunikacji. Cechami tej odmiany języka były zawsze funkcjonalność, nastawienie na sprawy techniczne i wysoki stopień terminologizacji. Jest to język ukształtowany nie po to, by barwnie i plastycznie opisywać rzeczywistość, lecz by, przykładowo, nauczyć rekruta rozbierania i czyszczenia karabinu maszynowego czy też składania raportu o położeniu wojsk przeciwnika. Jego cechą jest hermetyczność - gdy wychodzi poza środowisko zawodowe żołnierzy, staje się niezrozumiały i nieprzystępny. Drugim źródłem dyskursu bezpieczeństwa, i nie mniej istotną przyczyną jego specyficznej jakości, są liczne wzory pochodzące z języka administracyjno-urzędowego, wnoszone z kolei przez państwowych urzędników i polityków zajmujących się bezpieczeństwem. O wadach i niskiej jakości komunikacyjnej tej odmiany polszczyzny wiele napisano, podkreślając, że jakość języka urzędowego wywiera bezpośredni wpływ na budowę państwa prawa i społeczeństwa obywatelskiego, będąc „niezbędnym warunkiem świadomego udziału Polaków w rządzeniu swoim krajem" (Deklaracja końcowa - I Kongres Języka Urzędowego 2012). Trzecim komponentem dyskursu, o równie specyficznej proweniencji, jest wkład akademickich ekspertów 
badających stosunki międzynarodowe. Dość powiedzieć, że jest to z kolei język o ambicjach naukowego porządkowania kategorii i pojęć oraz dokonania syntezy zjawisk związanych z obronnością i bezpieczeństwem, ale wnoszący również własne idiosynkrazje (jak nadmierne uteoretycznianie zagadnień lub abstrakcyjna niezrozumiałość). Na styku tych zjawisk powstają teksty - realizacje dyskursu - które bardzo często są formalnie i pojęciowo niespójne. Przyjrzyjmy się konkretnemu przykładowi.

W przedmowie do Białej księgi bezpieczeństwa narodowego Rzeczypospolitej Polskiej (2013, s. 5) prezydent Bronisław Komorowski pisze: „Ostatnie dwie dekady przyniosły wiele dynamicznych zmian w strategicznym środow isku bezpi e c zeństw a Polski. Globalizacja i rewolucja informacyjna przyczyniły się do powiązania świata coraz ściślejszymi sieciami wzajemnych zależności”. Znamienne, że nawet $\mathrm{w}$ języku autora wstępu tak wyraźnie ujawniają się główne cechy dyskursu. „Biała księga" to ważny dokument, będący podsumowaniem dokonanego wcześniej przez ekspertów „strategicznego przeglądu bezpieczeństwa narodowego”. Stanowi typowy przykład komunikacji władzy, ekspertów i obywateli. Jednak już wstępna analiza prowadzi do wniosku, że już na poziomie uzgodnienia znaczeń podstawowych pojęć mamy do czynienia z dyskursem zasadniczo niespójnym.

Po pierwsze, „bezpieczeństwo” rozumiane jest w tym dokumencie w sposób zreifikowany, materialny - traktuje się je niczym cenny przedmiot, którego trzeba strzec, który istnieje niejako w oderwaniu od ludzi, którzy na co dzień o nim myślą i którzy chcą czuć się bezpieczni. $Z$ punktu widzenia semantyki i logiki jezzyka polskiego, przyjęte tutaj formalnie (w specjalnym załączniku z wykazem głównych definicji) definicje bezpieczeństwa są wielce intrygujące. Bezpieczeństwo określa się jako „t e o r i ę i prak ty k ę zapewniania możliwości przetrwania (egzystencji) i realizacji własnych interesów przez dany podmiot" (Biała księga..., s. 247). Nie jest to jasne. Czy analogicznie powiedzielibyśmy, że np. wolność - to „wyjaśnianie i działanie w taki sposób, żeby ludzie nie byli niczym ograniczeni'? W tej definicji brakuje istoty definiowanego zjawiska (choć nie brakuje szablonu definicyjnego, znanego choćby ze studium wojskowego w dawnych czasach). Idźmy dalej. Okazuje się, że „podmiot bezpieczeństwa” to... „każdy świadomie istniejący i celowo działający... p o d m i o t (indywidualny lub zbiorowy), rozpatrywany z punktu widzenia jego bezpieczeństwa" (Biała ksiegga..., s. 247). Mamy tu dwa problemy. Po pierwsze, autor zakłada istnienie nieświadomie działających podmiotów. Po drugie, cała definicja jest tautologią. Mówiąc innymi słowy: podmiotem bezpieczeństwa jest ... podmiot, o którego bezpieczeństwie mówimy. Co ważniejsze, reifikując kluczowe pojęcie autorzy polskiej strategii bezpieczeństwa narodowego przyjmują założenie, że „bezpieczeństwo" istnieje niejako niezależnie od czynników społecznych, że jest czymś o cechach materialnych, składnikiem przyrody (geografii?); do tego zakładają że podmiotem jest zarówno przedmiot naszych dywagacji, jak i grupa bądź organizacja, która dąży do realizacji swoich interesów [czyli w gruncie rzeczy dopiero buduje swoją podmiotowośćc.

Po trzecie, główne definicje zakładają, że główne zagrożenia powstają dzięki czynnikom zewnętrznym, otoczeniu. Dlatego jednym z kluczowych pojęć dyskursu jest „środowisko bezpieczeństwa”, które z kolei formalnie definiuje się jako „zewnętrzne i... w e w n ętr zne, militarne i niemilitarne (cywilne) wa r u n k i bezpieczeństwa (w a r u n k i realizacji interesów danego podmiotu w dziedzinie bezpieczeństwa i osiągania ustalonych przezeń celów w tym zakresie...") (Biała księga ..., s. 247). Zapominając 
o oksymoronie ,,wewnętrzne środowisko”, zrekonstruujmy ponownie przyjęte w tym dyskursie określenie bezpieczeństwa. Wynika z niego, że „,bezpieczeństwo” to nasze „działanie" [każde działanie ma swój podmiot], polegające na zapewnianiu przez nas przetrwania „tym, o których mówimy” w kategoriach bezpieczeństwa. Jest równocześnie działaniem nadrzędnego podmiotu (polityków, generałów - twórców strategii), jak i materialnym bytem, wymagającym ochrony (wszechobecne założenie). Tych, których chronimy, nazywamy „podmiotami bezpieczeństwa” (jakby sami mieli się chronić). Nie wyjaśnia niczego zapewnienie, że te podmioty dążą do realizacji własnych interesów. Zagrożenia pochodzą ze strony zmiennego środowiska, które może być ,,wewnętrzne” i ,zewnętrzne”, rozumianego do tego jako „warunki bezpieczeństwa" ${ }^{2}$. Czy tego typu realizacja dyskursu (a jest to kluczowy dokument) sprzyja sensownej komunikacji? Nie można mieć wątpliwości, że o bezpieczeństwie można i należy mówić prościej, bardziej zrozumiale, logicznie i jednoznacznie. W analizowanym tekście treści są ukryte za nieprzyjaznym, niedostępnym językiem, który już na poziomie podstawowych definicji jest niejasny.

W krytycznej teorii dyskursu przyjmuje się, że dyskurs to coś więcej niż język - jest on zbiorem praktyk społecznych $\mathrm{i}$ instytucjonalnych wraz z towarzyszącymi im działaniami w zakresie przygotowania, realizacji i interpretacji. Teksty (i inne ekspresje) to realizacje dyskursu, który ujawnia głębiej osadzoną w procesach historycznych wiedzę i „pamięć instytucji”. Jeśli tak założyć, to polski dyskurs bezpieczeństwa jest odspołeczny co najmniej w dwu znaczeniach: od normalnej komunikacji społecznej odróżnia się ze względu na swoją nieprzystępność i niespójność, a od powszechnego rozumienia bezpieczeństwa przez Polaków odróżnia się ze względu na swoją treściową hermetyczność (odnosząc się głównie do wąsko określonego bezpieczeństwa państwa). Istnieje proste wytłumaczenie tego stanu rzeczy: być może, polski oficjalny dyskurs bezpieczeństwa, w przeświadczeniu jego twórców, jest wewnętrzną sprawą środowiska generałów, polityków i ekspertów akademickich. Jeśli tak jest, to za cenę pogłębiającej się nieufności wobec państwa, które - sądząc z właściwości dyskursu - chce strzec naszego bezpieczeństwa w sposób niespójny i odspołeczny.

\section{Wnioski}

Dominujący redukcjonizm w podejściu do bezpieczeństwa Polski i Polaków, jak również jakość samego dyskursu publicznego w tym zakresie rodzi przynajmniej dwa pytania. Czy dbający o nasze bezpieczeństwo politycy powinni uwzględniać szerszą i głębszą wiedzę społeczną, w tym stan i dynamikę świadomości społecznej, podczas podejmowania decyzji na temat naszego bezpieczeństwa - czy też wystarczające jest opacie się na tradycyjnych, profesjonalnych formułach generałów i strategów, skupiających się na geopolitycznych zagrożeniach granic? Czy komunikacja władzy z ludźmi na temat zbiorowego bezpieczeństwa jest realnym czynnikiem, kształtującym nasze zbiorowe bezpieczeństwo?

W moim przekonaniu pierwsze pytanie ma retoryczny charakter. Krytyczne podejście do studiów nad bezpieczeństwem zakłada m.in., że nie powinno być ostrej granicy

${ }^{12}$ Konkretnie: ,warunki realizacji interesów danego podmiotu w dziedzinie bezpieczeństwa i osiągania ustalonych przezeń celów w tym zakresie, charakteryzowane przy pomocy czterech podstawowych kategorii, jakimi są: szanse, wyzwania, ryzyka i zagrożenia" (Biała księga, s. 247). 
między działalnością naukową i teoretyczną a praktykami zapewniania bezpieczeństwa przez polityków. Nie ma żadnego powodu, by nie poddawać krytycznej analizie - z perspektywy szerokiej wiedzy społecznej - ustaleń ekspertów i generałów. Chodzi o to, żeby dla wspólnego dobra praktycy zajmujący się bezpieczeństwem byli bardziej refleksyjni i samokrytyczni.

Drugie pytanie jest nieco trudniejsze. Zgodnie z założeniami teorii krytycznej każda analiza obejmująca tak istotne dla wspólnoty zagadnienia jak bezpieczeństwo może wywrzeć skutek polityczny, podobnie jak każda realizacja dyskursu bezpieczeństwa wywiera konkretne skutki społeczne. Przedstawiona w tekście, oparta na przykładach z Białej księgi bezpieczeństwa narodowego Rzeczypospolitej Polskiej z 2013 roku analiza polskiego oficjalnego dyskursu bezpieczeństwa prowadzi do wniosku, że ów dyskurs może prowadzić do pogłębienia nieufności ludzi do władzy, ponieważ buduje niepotrzebne bariery komunikacyjne. Jest hybrydą trzech odmian języka, z których zdaje się czerpać głównie złe nawyki: środowiskowego żargonu wojskowego, języka kancelaryjnego oraz stylu naukowo-teoretycznego. W efekcie nie jest spójny na poziomie pojęciowo-definicyjnym, jest przeterminologizowany i nasycony językowymi szablonami. Ma niewiele wspólnego ze sposobem myślenia i mówienia większości ludzi, dla których bezpieczeństwo osobiste czy zbiorowe jest tylko jedną z wartości uwikłanych w system priorytetów i celów szczęśliwego życia i wcale nie musi być wartością nadrzędną.

\section{Bibliografia}

Bartmiński J. (red.) (2006), Język, wartości, polityka. Zmiany rozumienia nazw wartości w okresie transformacji ustrojowej w Polsce. Raport z badań empirycznych, Wydawnictwo UMCS, Lublin.

Biała księga bezpieczeństwa narodowego Rzeczypospolitej Polskiej (2013), Biuro Bezpieczeństwa Narodowego, Warszawa.

Bigo D. (1998), L'Europe de la sécurité intérieure, Penser autrement la sécurité [Europe of Internal Security, Thinking Security Differently], w: Entre Union et Nation. L'Etat en Europe [Between Union and Nation, the State in Europe], red. A.-M. Le Gloannec, Presses de Sciences Po, Paris, s. $55-90$.

Bigo D. (2000), When Two Become One: Internal and External Securitisations in Europe, w: International Relations Theory and the Politics of European Integration, Power, Security and Community, red. M. Kelstrup, M. C. Williams, Routledge, London, s. 171-205.

Booth K. (1991), Security and Emancipation, „Review of International Relations” 17 (4), s. 313-326.

Buzan B. (1984), Peace, Power, and Security: Contending Concepts in the Study of International Relations, „Journal of Peace Research”, 21(2), s. 109-125.

Buzan B., Wæver O., de Wilde J. (1998), Security: A New Framework for Analysis, Lynne Rienner, Boulder, CO.

C.A.S.E. Collective (2006), Critical Approaches to Security in Europe: A Networked Manifesto, SAGE Publications, vol. 37(4), p. 443-487, http://sdi.sagepub.com.

Deklaracja końcowa - I Kongres Języka Urzędowego, Senat RP, 31.10.2012, http://www.jezykurzedowy.pl/pl/I-Kongres.

Diagnoza społeczna 2015. Warunki i jakość życia Polaków, raport (2015), red. J. Czapiński, T. Panek, Rada Monitoringu Społecznego, Warszawa.

EB 84 (2015), Standard Eurobarometer, Public opinion in the European Union, First Results, Autumn, European Union, http://ec.europa.eu/public_opinion/index_en.htm. 
EB/EP 84.1 (2015), Eurobarometr Parlamentu Europejskiego, Główne wyzwania dla UE, migracja oraz sytuacja gospodarcza i społeczna, cz. I, Unia Europejska, jesień, http://ec.europa.eu/public_opinion/index_en.htm.

Informacja o zadaniach polskiej polityki zagranicznej w 2016 r. (2016), wystapienie Ministra Spraw Zagranicznych Witolda Waszczykowskiego, Sejm RP, http://www.tvn24.pl/minister-waszczykowski-w-sejmie-cale-wystapienie,614739,s.html.

Kołodziej J. (2011), Wartości polityczne. Rozpoznanie, rozumienie, komunikowanie, Księgarnia Akademicka, Kraków.

McDonald M., Browning Ch. S. (2013), The future of critical security studies: Ethics and the politics of security, „European Journal of International Relations”, June 1, vol. 19, s. 235-255.

McDonald M. (2008), Securitization and the Construction of Security, „European Journal of International Relations", December, vol. 14, 4, s. 563-587.

Pisarek W. (2002), Polskie stowa sztandarowe i ich publiczność, Ośrodek Badań Prasoznawczych, Kraków 2002.

Popper K. R. (1947), The Open Society and its Enemies, 2nd ed., vol. 2, ch. 21, The High Tide of Prophecy: Hegel, Marx, and the Aftermath, George Routledge and Sons Ltd., London.

Sheehan M. (1999), Community, Anarchy and Critical Security, Paper for the ECPR Joint Sessions workshop Redefining Security, Mannheim, 26-31 March 1999, http://www.anarchist-studiesnetwork.org.uk/documents/Anarchy_and_Security.doc.

Taylor Ch. (2010), Nowoczesne imginaria społeczne, przeł. A. Puchejda, K. Szymaniak, Wydawnictwo Znak, Kraków.

Wæver O. (2004a), Peace and Security: Two Concepts and Their Relationship, w: Contemporary Security Analysis and Copenhagen Peace Research, red. S. Guzzini, D. Jung, Routledge, London, s. $53-65$.

Wæver O. (2004b), Aberystwyth, Paris, Copenhagen: New „Schools” in Security Theory and Their Origins Between Core and Periphery", paper presented at the 45th Annual Convention of the International Studies Association, Montreal, Canada, 17-20 March.

Wyn J. R. (1999), Security, Strategy, and Critical Theory, Lynne Rienner, London.

\section{Threats Present in the Polish Social Consciousness in the Light of Critical Security Theory}

\section{Summary}

Polish security as a subject and object of public discourse is typically reduced to the military security of the state. Research has indicated, however, that a majority of Poles have a different approach to security (primarily caring for their well-being and social matters within their immediate surroundings), which actually conforms to the system of private and collective values. This paper illustrates the extent to which the way the ordinary people understand security differs from the official language employed by generals, politicians and other experts. The analysis of selected samples of the official security discourse conducted in this paper leads to the conclusion that this discourse uses three different language variations producing fundamental communications obstacles. These variants include the dominant jargon of professional officers in command and officers-instructors, an administrative and official language and an abstract language of academic experts who examine international relations. The paper is written from the point of view of critical security theory and is based on the results of representative surveys of Poles.

Key words: critical security theory, security discourse, collective values, semantic analysis 